\title{
Analisis Komposisi Biodiesel Hasil Konversi Minyak Biji Carica (Carica pubescens) Menggunakan Enzim Lipase Bekatul
}

\author{
Reni Banowati Istiningrum ${ }^{\mathrm{a}^{*}}$, Hastin Nurrokhmah ${ }^{\mathrm{a}}$, Astri Sri Wahyuni ${ }^{\mathrm{a}}$ \\ ${ }^{a}$ Prodi DIII Analisis Kimia FMIPA Universitas Islam Indonesia \\ *corresponding author : reni_banowati@uii.ac.id
}

\begin{tabular}{l} 
ARTIKEL INFO \\
\hline Received : 05 Juli 2018 \\
Revised : 01 Agustus 2018 \\
Published : 28 September 2018 \\
Kata kunci : enzim lipase, bekatul, \\
minyak biji carica, biodiesel, rasio \\
molar minyak/metanol
\end{tabular}

\begin{abstract}
ABSTRAK
Peningkatan konsumsi bahan bakar berbasis fosil mendorong berbagai penelitian untuk memproduksi bahan bakar yang bersifat terbarukan salah satunya biodiesel. Biodiesel adalah bahan bakar yang bersumber dari minyak nabati serta ramah lingkungan. Minyak biji carica berpotensi sebagai sumber minyak nabati untuk produksi biodiesel karena merupakan limbah home industry pengolahan buah carica dari Kabupaten Wonosobo dan merupakan nonedible oil. Penelitian ini bertujuan untuk memproduksi biodesel dari minyak biji carica secara enzimatis menggunakan enzim lipase yang diekstrak dari bekatul. Hasil penelitian ini menunjukkan sebesar 50,36 \% minyak dapat diekstrak dari biji carica kering dengan komposisi terbesarnya adalah asam oleat. Enzim lipase dapat diekstrak dari bekatul menggunakan buffer $\mathrm{pH}$ 5,5 dengan nilai aktivitas sebesar 14,72 $\mathrm{U} / \mathrm{mL}$. Ekstrak enzim lipase ini juga menunjukkan sifat stabil selama penyimpanan 15 hari. Minyak biji carica berhasil dikonversi menjadi biodiesel dengan rasio molar minyak : metanol optimum adalah 1: 6 dan rendemen yang dihasilkan sebesar $65,86 \%$ dengan kadar metil ester sebesar $98,7 \%$ relatif.
\end{abstract}

\section{PENDAHULUAN}

Konsumsi BBM yang semakin meningkat berimbas pada semakin menipisnya cadangan bahan bakar minyak bumi. Fenomena ini mendorong munculnya berbagai penelitian untuk menemukan bahan bakar alternatif terbarukan pengganti bahan bakar berbasis fosil tersebut. Salah satu sumber energi terbarukan adalah minyak nabati yang dapat diolah menjadi biodiesel. Biodiesel merupakan bahan bakar ramah lingkungan karena emisinya tidak mengandung sulfur yang berpotensi menyebabkan hujan asam. Biodiesel juga merupakan carbon neutral fuel karena karbon yang dilepaskan pada pembakaran biodiesel adalah karbon yang dipakai untuk fotosintesis oleh tanaman sumber bahan baku biodiesel [1].

Biodiesel merupakan metil ester dari asam lemak rantai panjang yang berasal dari lemak yang dapat diperbarui seperti minyak nabati atau hewani. Minyak nabati atau hewani yang dapat dibudidayakan dan kemudian dipanen memberikan sifat terbarukan bagi biodiesel. Beberapa penelitian telah dilakukan untuk memproduksi biodiesel dari minyak nabati yaitu dari minyak kapuk randu [2], minyak jarak pagar [3], minyak kemiri [4], minyak biji kapuk [5], minyak kacang kedelai [6], minyak biji manggis [7], minyak biji karet [8], minyak biji apokat [9], minyak biji papaya dan biji rambutan [10].

Salah satu bahan alami yang potensial untuk dijadikan bahan baku biodiesel adalah biji buah carica. Carica adalah komoditi pangan lokal Kabupaten Wonosobo yang tumbuh di kawasan Lembah Dieng, Wonosobo dengan masa panen pohon seumur hidup. Carica diproduksi dalam usaha home industry seperti sirup, dodol, manisan, dan keripik buah carica sedangkan biji buah carica dapat 
dioptimalkan menjadi salah satu sumber bahan minyak nabati. Biji buah carica memiliki kadar air 4,6\%, abu 4,9\%, protein 2,1\%, lemak 7,9\%, serat kasar 1,9\%, dan karbohidrat 37,9\% dan dapat menghasilkan minyak sebesar 33,3 \% sampai 53,33 \% [11]. Kandungan minyak biji carica yang cukup tinggi memiliki potensi untuk menjadi bahan baku pembuatan biodisel.

Pada skala industri, produksi biodiesel umumnya dilakukan melalui reaksi antara trigliserida dari minyak nabati dengan alkohol menggunakan katalis asam atau basa yang disebut reaksi transesterifikasi. Alkohol yang umum digunakan adalah metanol dengan hasil reaksi berupa metil ester. Metil ester inilah yang kemudian dikenal dengan biodiesel. Melalui reaksi transesterifikasi, gliserol dan komponen penyumbang viskositas dihilangkan sehingga dihasilkan biodiesel dengan viskositas yang rendah menyamai bahan bakar fosil [1].

Transesterifikasi dengan cara kimiawi, yaitu menggunakan katalis asam atau basa, memiliki beberapa kelemahan diantaranya membutuhkan energi dan metanol yang tinggi, transerterifikasi tidak sempurna jika kandungan asam lemak bebas dan air pada minyak tinggi, sulit memisahkan katalis dan produk sampingnya yaitu gliserol sehingga membutuhkan proses pencucian secara bertahap dan masalah pembuangan sabun sebagai hasil samping transesterifikasi menggunakan katalis basa [12][1][13][14]. Oleh karena itu diperlukan suatu proses yang lebih efektif dengan meminimalkan konsumsi energi dan bahan kimia yaitu transesterifikasi secara enzimatis menggunakan enzim lipase.

Produksi biodiesel secara enzimatis menggunakan enzim lipase telah dilakukan dengan menggunakan berbagai minyak nabati misalnya minyak biji karet [13], minyak jelantah [15], minyak biji kapas [12], minyak biji pepaya dan minyak biji rambutan [10]. Enzim lipase yang digunakan sebagai katalis berasal dari enzim lipase komersial seperti enzim lipase C.Antartica dan P. Cepacia [15] dan C.Rugosa. Namun dari sekian kelebihan proses transesterifikasi enzimatis terdapat satu kekurangan yaitu enzim lipase komersial tidak ekonomis karena harganya yang mahal. Oleh karena itu diperlukan sumber enzim lipase yang ekonomis namun tetap memiliki aktivitas katalitik yang tinggi yang diekstrak langsung dari bahan alami (indigenous). Beberapa penelitian telah dilakukan untuk mengkaji aktivitas enzim lipase indigenous dari bekatul dan lateks papaya [13][16] serta dari dedak padi [17]. Penelitian ini akan mengkaji aktivitas enzim lipase yang diekstrak dari bekatul sebagai biokatalis pada pembuatan biodiesel dari minyak biji carica sebagai metode yang bersifat low cost.

\section{METODE}

\subsection{Alat dan Bahan}

Alat yang digunakan dalam penelitian ini antara lain peralatan gelas, magnetic stirer, neraca analitik (Ohaus), sentrifugasi (Thermo), klem, statif, oven (Memert), sokhlet, evaporator Buchii, corong pisah, Gas Chromatography - Mass Spectrofotometer (GC-MS) QP-2010-SE, seperangkat alat refluks.

Bahan-bahan yang digunakan dalam penelitian ini adalah bekatul, akuades, buffer fospat $0,05 \mathrm{M}$ (pH 5,5; $6: 6,5: 7)$, dietil eter teknis, minyak goreng sawit, larutan aseton:alkohol (1:1), indikator fenolftalaein, $\mathrm{NaOH} 0,05 \mathrm{~N}$, kalium hidrogenftalat, n-hekasana

\subsection{Prosedur Kerja}

\section{Ekstraksi minyak biji carica}

Biji carica dikeringkan pada temperatur $60^{\circ} \mathrm{C}$ selama 4 jam kemudian ditumbuk menjadi serbuk. Serbuk biji carica diekstrak dengan metode soxhlet extraction menggunakan pelarut $\mathrm{n}$-heksan pada temperatur $77{ }^{\circ} \mathrm{C}$. Hasil ekstraksi dievaporasi menggunakan evaporator buchi pada temperatur 77 ${ }^{\circ} \mathrm{C}$ dan minyak yang dihasilkan kemudian disaring dan diukur rendemennya. Kompisisi kimia minyak biji carica dianalisis dengan GC-MS.

\section{Ekstraksi enzim lipase dari bekatul}

Sebanyak 10 gram bekatul ditambah $50 \mathrm{~mL}$ dietil eter. Campuran diaduk dengan magnetic stirrer selama 30 menit kemudian disaring dan dicuci residunya dengan dietil eter. Residu dikeringkan dalam udara terbuka selama 1 jam kemudian ditambah dengan $40 \mathrm{~mL}$ buffer fospat $0,05 \mathrm{M}(\mathrm{pH} 5,5$ 
; $6: 6,5: 7)$. Larutan campuran disaring dengan menggunakan kertas saring. Filtrat hasil penyaringan disentrifugasi dengan kecepatan $50 \mathrm{rpm}$ selama 15 menit dan diambil supernatannya. Supernatan berupa enzim lipase kasar diinkubasi pada temperatur $4^{\circ} \mathrm{C}$.

\section{Penentuan aktivitas enzim lipase}

Sebanyak 2 gram minyak goreng sawit ditimbang dalam erlenmeyer kemudian ditambah $1 \mathrm{~mL}$ larutan enzim lipase dan $4 \mathrm{~mL}$ buffer fospat $(\mathrm{pH} 5,5 ; 6 ; 6,5 ; 7)$. Campuran diaduk dengan menggunakan hotplate stirrer selama 1 jam dan temperatur $35^{\circ} \mathrm{C}$ kemudian ditambah $10 \mathrm{~mL}$ aseton : alkohol (1:1) dan diaduk hingga homogen. Larutan dititrasi dengan menggunakan $\mathrm{NaOH} \mathrm{0,05} \mathrm{N}$ dan indikator fenolftalein. Larutan blanko dibuat dengan cara yang sama dengan sampel tanpa enzim dan tanpa inkubasi. Aktivitas enzim ditentukan dengan persamaan (1).

Aktivitas enzim $(\mathrm{U} / \mathrm{mL})=\frac{(\mathrm{A}-\mathrm{B}) \times \mathrm{N}}{\mathrm{V} \times 60} \times 1000$

Keterangan:

A : volume $\mathrm{NaOH}$ untuk titrasi sampel $(\mathrm{mL})$

B : volume $\mathrm{NaOH}$ untuk titrasi blangko $(\mathrm{mL})$

$\mathrm{N}$ : molaritas $\mathrm{NaOH}(\mathrm{M})$

1000 : konversi dari mmol ke $\mu \mathrm{mol}$

$\mathrm{V} \quad$ : volume enzim $(\mathrm{mL})$

60 : waktu inkubasi (menit)

\section{Pengujian stabilitas enzim lipase}

Sebanyak 2 gram minyak goreng sawit ditambahkan dengan $1 \mathrm{~mL}$ larutan enzim (yang disimpan selama $1,2,3,4,5,6,7,8,9,10,11,12,13,14,15$ hari) dan $4 \mathrm{~mL}$ larutan buffer fosfat $0,05 \mathrm{M} \mathrm{pH}$ optimum. Aktivitas enzim ditentukan setiap hari selama 15 hari.

\section{Pembuatan biodiesel dengan variasi rasio minyak : metanol}

Sebanyak $10 \mathrm{~g}$ minyak biji carica dimasukan ke dalam labu alas bulat, ditambahkan $1 \mathrm{~mL}$ enzim lipase dan direfluks selama 2 jam pada temperatur $37^{\circ} \mathrm{C}$, kemudian ditambah metanol dengan rasio minyak metanol $(1: 2 ; 1: 4 ; 1: 6 ; 1: 8)$. Refluks dilanjutkan kembali selama 22 jam pada temperatur $50^{\circ} \mathrm{C}$ dengan pengadukan konstan $(250 \mathrm{rpm})$. Larutan kemudian didinginkan pada temperatur kamar dan dimasukan ke dalam corong pisah, dibiarkan selama semalam. Lapisan yang tidak larut dalam air diambil lalu dilakukan pencucian menggunakan akuades hangat, pencucian diulangi sebanyak 3 kali. Biodiesel yang telah dicuci kemudian dipanaskan pada temperatur $110^{\circ} \mathrm{C}$ untuk menghilangkan kadar air kemudian ditimbang dan dihitung rendemennya dengan menggunakan persamaan (2). Adapun kadar metil ester ditentukan dengan GC-MS.

Rendemen biodiesel $(\%)=\frac{\mathrm{B}}{\mathrm{C}} \times 100$

Keterangan

B : masa biodiesel yang dihasilkan $(\mathrm{g})$

C : masa minyak biji carica $(\mathrm{g})$

\section{HASIL PENELITIAN}

\subsection{Ekstraksi minyak biji carica}

Minyak biji carica diekstrak dari biji carica yang sudah dikeringkan dan dihaluskan menggunakan pelarut $n$-heksana dengan metode sokhletasi. Ekstraksi dilakukan selama 2 jam dan pelarut dievaporasi sehingga diperoleh minyak biji carica. Komponen asam lemak dalam minyak ditentukan menggunakan instrumen GC-MS. Rendemen minyak biji carica ditunjukkan pada Tabel 1 sedangkan komponen asam lemaknya ditunjukkan pada Tabel 2. Rendemen minyak biji carica yang dihasilkan sebesar 50,36\% dari masa berat kering. Dari data kromatogram, minyak biji carica mengandung tiga komponen asam lemak yaitu asam palmitat, asam oleat dan linoleat dengan 
komponen terbesarnya adalah asam oleat yaitu $72,98 \%$ relatif dengan berat molekul $282,47 \mathrm{~g} / \mathrm{mol}$. Berat molekul ini digunakan untuk menentukan rasio molar minyak : metanol pada pembuatan biodiesel.

TABEL 1. Hasil ekstraksi minyak biji carica

\begin{tabular}{lll}
\hline Massa sampel $(\mathrm{g})$ & Massa minyak $(\mathrm{g})$ & Rendemen minyak $(\%)$ \\
\hline 50 & 25,1796 & 50,36 \\
\hline
\end{tabular}

TABEL 2. Komposisi minyak biji carica

\begin{tabular}{lll}
\hline Waktu retensi (menit) & Senyawa & Kadar (\%area) \\
\hline 33,717 & Asam palmitat & 14,74 \\
40,043 & Asam oleat & 72,98 \\
41,575 & Asam linoleat & 12,28 \\
\hline
\end{tabular}

\subsection{Ekstraksi dan uji stabilitas enzim lipase}

Sumber enzim lipase yang digunakan dalam penelitian ini adalah bekatul yang merupakan limbah penggilingan padi. Enzim lipase diekstrak menggunakan bufer dengan variasi $\mathrm{pH}$ antara 5,57. Sebelum diekstrak dengan bufer, lemak bekatul dihilangkan dahulu menggunakan dietil eter. Proses penghilangan lemak ini perlu dilakukan karena untuk menghindari proses hidrolisis lemak oleh enzim secara insitu karena ekstrak enzim lipase ini ditujukan untuk mengkatalisis reaksi hidrolisis lemak dari minyak biji carica dalam proses pembuatan biodiesel.

Penentuan aktivitas enzim lipase dilakukan dengan menggunakan minyak kelapa sawit komersial sebagai substratnya. Hidrolisis lemak dilakukan pada temperatur $35^{\circ} \mathrm{C}$ dengan pengadukan selama $1 \mathrm{jam}$. Asam lemak yang dihasilkan ditentukan secara titrasi asidimetri menggunakan larutan standar $\mathrm{NaOH} 0,05 \mathrm{M}$. Aktivitas enzim lipase bekatul pada berbagai pH ditunjukkan pada Gambar 1.

Gambar 1. menunjukkan bahwa aktivitas enzim lipase mengalami penurunan dengan meningkatnya $\mathrm{pH}$ pada rentang $\mathrm{pH}$ 5,5-7. Aktivitas enzim optimum pada $\mathrm{pH} 5,5$ dengan nilai aktivitas sebesar 14,72 U/mL. Enzim dapat bekerja pada $\mathrm{pH}$ optimum, kondisi lingkungan yang jauh dari kondisi optimum akan menyebabkan enzim tidak aktif. Enzim merupakan protein yang akan mengalami kerusakan struktur (terdenaturasi) apabila kondisi lingkungan ekstrim sehingga mempengaruhi aktivitasnya [18].

Uji stabilitas enzim lipase dilakukan dengan memantau aktivitasnya selama selama disimpan dalam rentang waktu tertentu. Pada penelitian ini rentang waktu penyimpanan adalah 1 sampai 15 hari pada temperatur $4{ }^{\circ} \mathrm{C}$. Uji stabilitas dari enzim lipase dilakukan dengan membuat bagan kendali yang terdiri dari Upper Control Limit (UCL) yang dihitung dari rata-rata+3SD, nilai rata-rata, batas kendali bawah (Lower Control Limit) yang dihitung dari rata-rata-3SD, serta data aktivitas enzim lipase per hari. Hasil uji stabilitas enzim lipase selama penyimpanan ditunjukkan pada Gambar 2.

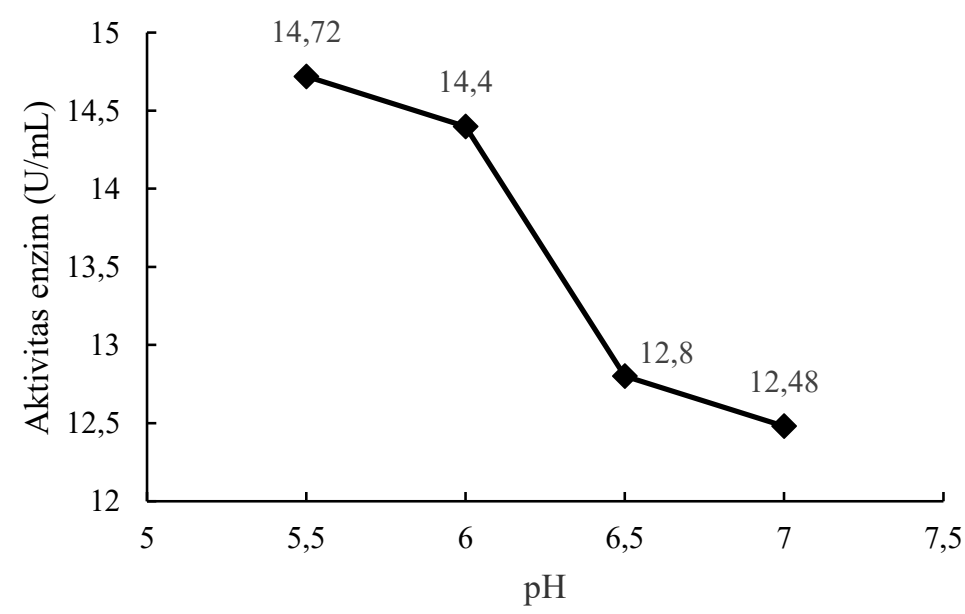

Gambar 1. Aktivitas enzim lipase berdasarkan variasi $\mathrm{pH}$ 


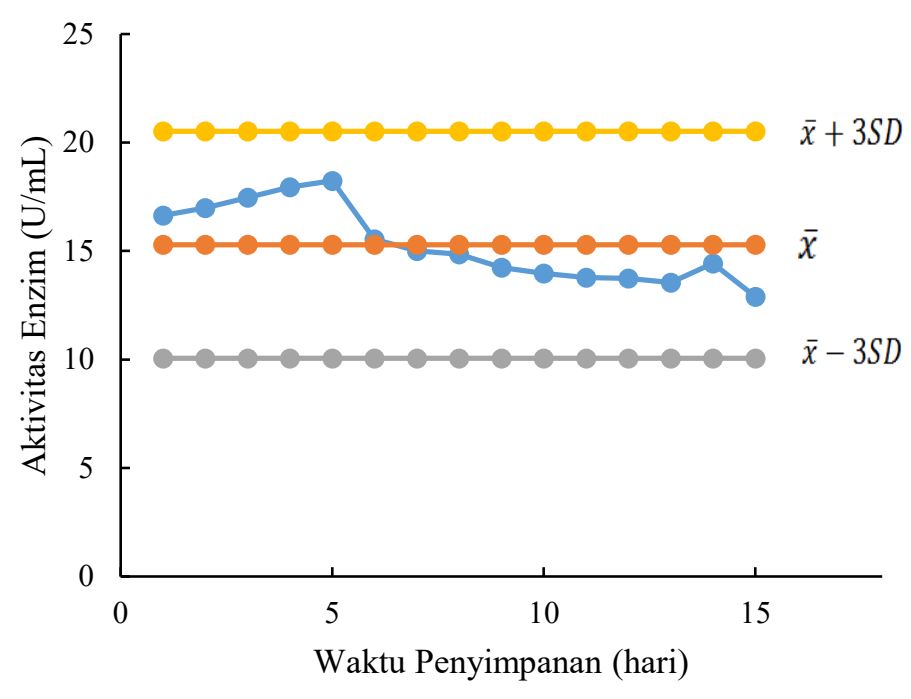

Gambar 2. Uji stabilitas enzim lipase berdasarkan lama penyimpanan

Gambar 2. menunjukkan bahwa enzim masih stabil selama masa penyimpanan 15 hari pada temperatur $4{ }^{\circ} \mathrm{C}$. Hal ini ditunjukkan dari tidak adanya data outlier, semua titik menunujukkan data inlier dan melawati garis rata-rata. Sehingga dapat disimpulkan bahwa enzim masih akan memberikan aktivitas yang realtif sama selama penyimpanan 15 hari.

\subsection{Pengaruh rasio molar minyak : metanol pada transesterifikasi minyak biji carica}

Rasio minyak : metanol merupakan salah satu parameter reaksi yang perlu dioptimasi. Secara stoikiometri jumlah alkohol yang dibutuhkan untuk reaksi adalah 3 mol untuk setiap 1 mol trigliserida untuk memperoleh $3 \mathrm{~mol}$ alkil ester dan $1 \mathrm{~mol}$ gliserol. Semakin banyak jumlah alkohol yang digunakan maka konversi biodiesel yang dihasilkan juga akan semakin banyak.

Gambar 3. menunjukkan bahwa terdapat tiga komponen utama dalam biodiesel. Dari masingmasing kromatogram terdapat satu puncak yang paling dominan dan berada pada waktu retensi yang sama yaitu pada 17,9 menit (puncak nomor 2). Dari hasil identifikasi Mass Spectrometry, puncak pada waktu retensi tersebut menunjukkan senyawa metil oleat. Dari Gambar 4. dapat dilihat bahwa semakin tinggi rasio molar minyak : metanol maka kadar relatif biodiesel juga semakin tinggi, dan mencapai optimum pada rasio 1:6 yaitu sebesar 98,7 \%. Pada rasio 1:8 kadar metil ester justru menurun yang menunjukkan bahwa semakin besar jumlah metanol akan mempengaruhi kinerja enzim. Semakin tinggi jumlah metanol menyebabkan deaktivitasi enzim lipase [10] atau menipisnya jumlah substrat [19]. Adapun komposisi biodiesel pada rasio minyak : metanol optimum ditunjukkan pada Tabel 3. Sedangkan perbandingan hasil penelitian ini dengan penelitian lain ditunjukkan pada Tabel 4.

TABEL 3. Komposisi biodiesel pada variasi rasio minyak : metanol 1: 6

\begin{tabular}{lllll}
\hline Nomor puncak & $\begin{array}{l}\text { Waktu retensi } \\
\text { (menit) }\end{array}$ & Senyawa & $\mathrm{Mr}(\mathrm{g} / \mathrm{mol})$ & $\begin{array}{l}\text { Kadar } \\
\text { (\%relatif) }\end{array}$ \\
\hline 1 & 16,082 & Metil palmitat & 270 & 8,02 \\
2 & 17,913 & Metil oleat & 296 & 87,43 \\
3 & 18,111 & Metil stearat & 298 & 3,25 \\
\hline & & & Total & 98,7 \\
\hline
\end{tabular}




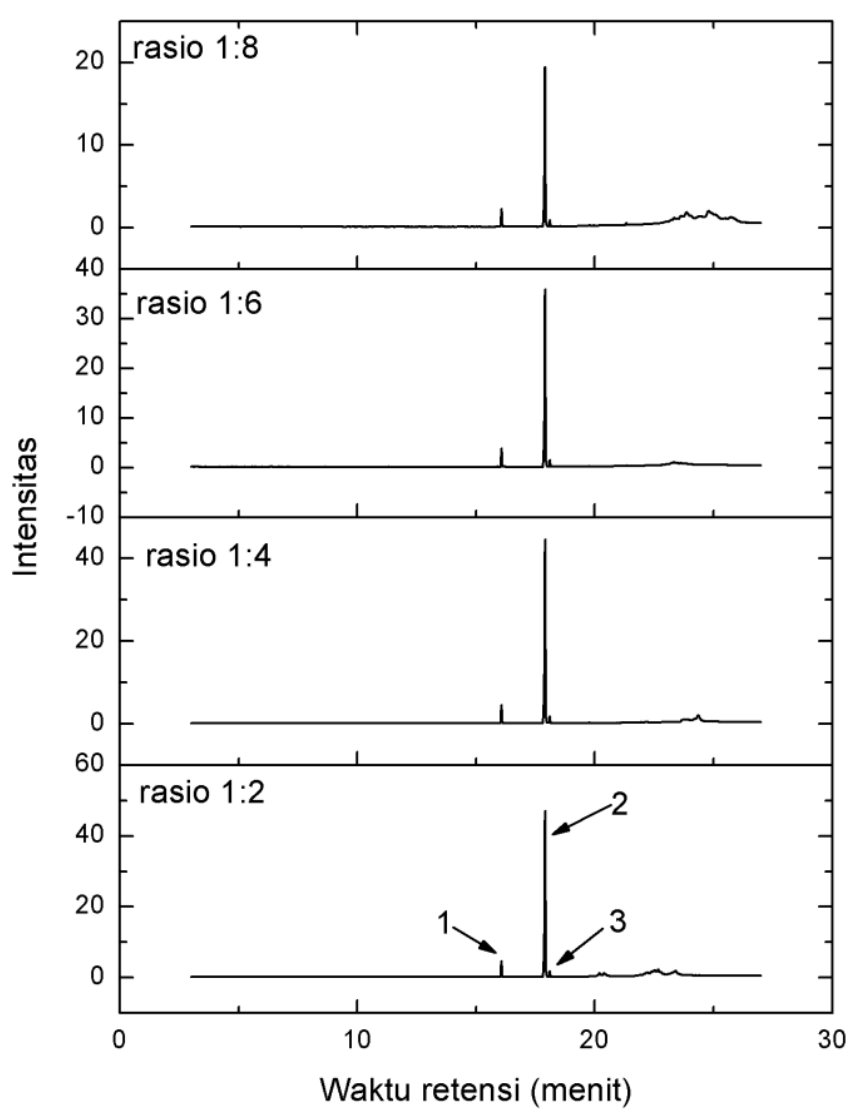

Gambar 3. Kromatogram biodiesel dengan variasi rasio molar minyak : metanol

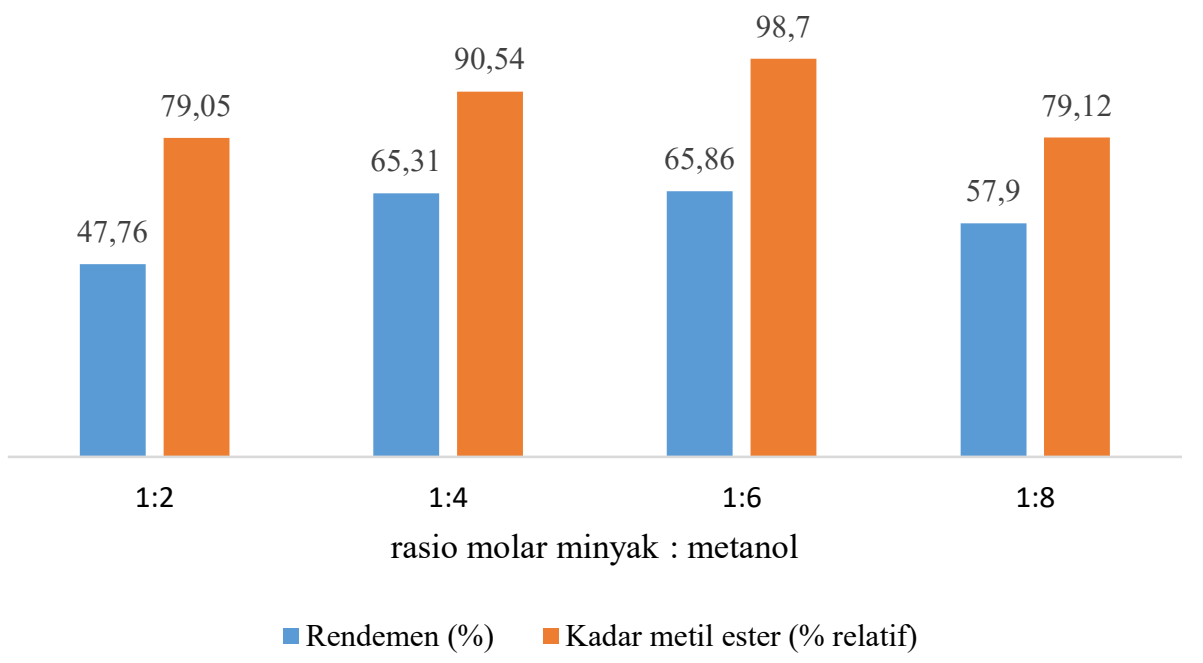

Gambar 4. Rendemen dan kadar metil ester biodiesel berdasar variasi rasio molar minyak : metanol 
TABEL 4. Perbandingan konversi biodiesel dari minyak nabati secara enzimatis dengan berbagai variasi rasio molar minyak : metanol

\begin{tabular}{lllll}
\hline Minyak nabati & Sumber enzim lipase & $\begin{array}{l}\text { Rasio molar } \\
\text { optmum }\end{array}$ & $\begin{array}{l}\text { Rendemen } \\
(\%)\end{array}$ & Sumber \\
\hline Minyak biji karet & $\begin{array}{l}\text { C.antartica lipase B } \\
\text { terimobilisasi pada } \\
\text { poliakrilat bead }\end{array}$ & $1: 6$ & 81,18 & {$[20]$} \\
$\begin{array}{l}\text { Minyak biji } \\
\text { pepaya }\end{array}$ & C.rugosa & $1: 6$ & 96 & {$[10]$} \\
$\begin{array}{l}\text { Minyak biji } \\
\text { rambutan }\end{array}$ & C.rugosa & $1: 8$ & 89 & {$[10]$} \\
Minyak jelantah & Novozym 435 & $1: 25$ & 89,1 & {$[19]$} \\
Minyak biji carica & Ekstrak lipase dari bekatul & $1: 6$ & 65,86 & Penelitian ini \\
\hline
\end{tabular}

\section{KESIMPULAN}

Berdasarkan hasil penelitian dapat disimpulkan bahwa minyak biji carica potensial sebagai sumber minyak nabati untuk bahan baku pembuatan biodiesel secara enzimatis. Selain itu, enzim lipase dari bekatul juga terbukti dapat mengkonversi minyak biji carica menjadi metil ester dengan aktivitasnya mencapai $14,72 \mathrm{U} / \mathrm{mL}$ dan stabil selama penyimpanan 15 hari pada temperatur $4{ }^{\circ} \mathrm{C}$. Walaupun rendemen biodiesel belum optimal yaitu hanya mencapai $65,86 \%$, namun kadar relatif metil esternya mencapai $98,7 \%$ dengan komposisi metil ester terbesarnya adalah metil oleat sesuai dengan kandungan asam lemak pada minyak biji carica.

\section{Ucapan Terima Kasih}

Penulis mengucapkan terimakasih kepada Direktorat Penelitian dan Pengabdian Masyarakat Universitas Islam Indonesia (DPPM UII) yang telah memberikan dana untuk penelitian ini melalui Hibah Penelitian Madya.

\section{Daftar Pustaka}

[1] S. V. Ranganathan and S. L. Narasimhan, "An overview of enzymatic production of biodiesel," Bioresour. Technol., vol. 99, pp. 3975-3981, 2008.

[2] S. Darmanto, “Analisa unjuk kerja biodiesel kapuk randu," Traksi, vol. 10, no. 2, pp. 1-10, 2010.

[3] D. Hasahatan, J. Sunaryo, and L. N. Komariah, "Pengeruh Ratio H2SO4 dan Waktu Reaksi terhadap Kuantitas dan Kualitas Biodiesel dari Minyak Jarak Pagar," J. Tek. Kim., vol. 18, no. 2, pp. 26-36, 2012.

[4] F. Mulana, "Penggunaan Katalis $\mathrm{NaOH}$ dalam Proses Transesterifikasi Minyak Kemiri menjadi Biodiesel," J. Rekayasa Kim. dan Lingkung., vol. 8, no. 2, pp. 73-78, 2011.

[5] A. S. Suryandari, S. N. Prasasti, and A. Roesyadi, "Pembuatan Biodiesel dari Minyak Biji Kapuk," J. Tek. Pomits, vol. 2, no. 1, pp. 1-5, 2013.

[6] A. . Akinsiku et al., "Biodiesel Fuel from Differently Sourced Local Seed Oils: Characterization, Effects of Catalysts, Total Glycerol Content and Flow Rates," Int. J. Sci. Eng. Res., vol. 4, no. 6, pp. 654-660, 2013.

[7] L. N. Aminah, S. T. Leong, Y. S. Wong, S. A. Ong, and C. K. Kairulazam, "Biodiesel 
Production of Garcinia Mangostana Linn . seeds by Two-Phase Solvent Extraction and Alkali-Catalyzed Transesterification," Int. J. Chem. Eng. Appl., vol. 4, no. 3, pp. 3-6, 2013.

[8] J. Gimbun et al., "Biodiesel Production from Rubber Seed Oil Using A Limestone Based Catalyst," Adv. Mater. Phys. Chem., vol. 2, no. December, pp. 138-141, 2012.

[9] H. M. Rachimoellah, D. A. Resti, A. Zibbeni, and I. W. Susila, "Production of Biodiesel through Transesterification of Avocado ( Persea gratissima ) Seed Oil Using Base Catalyst," J. Tek. Mesin, vol. 2, no. Oktober, pp. 85-90, 2009.

[10] C. S. Wong and R. Othman, "Biodiesel Production by Enzymatic Transesterification of Papaya Seed Oil and Rambutan Seed Oil," Int. J. Eng. Technol., vol. 6, no. 6, pp. 2773-2777, 2015.

[11] D. Larasati, Haslina, B. Kunarto, and R. Yulianti, "Pengaruh jenis pelarut pada pembuatan minyak makan biji carica dieng (CArica Candamarcensis Hok) Terhadap Kandungan Betakaroten dan Vitamin E (Tokoferol)," J. Teknol. Pangan dan Has. Pertan., vol. 8, no. 2, pp. 78-83, 2011.

[12] Y. X. Li and B. X. Dong, "Optimization of Lipase-Catalyzed Transesterification of Cotton Seed Oil for Biodiesel Production Using Response Surface Methodology," Biol. Appl. Sci., vol. 59, no. December, pp. 1-7, 2016.

[13] F. Arifan, M. E. Yulianto, and O. Yuariski, "Pengembangan Proses Enzimatis untuk Produksi Biodiesel dari Minyak Biji Karet," in Simposium Nasional RAPI, 2009, pp. 50-57.

[14] H. Wu, M. Zong, Q. Luo, and H. Wu, "Enzymatic Convertion OF Waste Oil to Biodiesel in A Solvent-Free System," Prepr.Pap.-Am.Chem.Soc., Div.Fuel Chem, vol. 48, no. 2, pp. 533534, 2003.

[15] S. Al-zuhair, "Enzymatic Production of Bio-Diesel from Waste Cooking Oil Using Lipase," Open Chem. Eng. J., vol. 435, pp. 84-88, 2008.

[16] R. Firyanto, J. D. Setiawan, and M. F. S. Mulyaningsih, "Perancangan Bioreaktor Packed Coloumn Enzymatis Penghasil Biodisel Secara Kontinyu," in Prosiding Seminar NAsional Teknik Kimia Kejuangan, 2011, pp. 1-4.

[17] A. Rajan and S. Poornima, "Biodiesel production from fried coconut oil using lipase extracted from rice bran," Int. J. Futur. Biotechnol., vol. 2, no. 2, pp. 10-15, 2013.

[18] R. A. Putranto and D. Santoso, "Karakterisasi gen penyandi lipase dari kapang Rhizopus oryzae dan Absidia corymbifera Karakterisasi gen penyandi lipase dari kapang Rhizopus oryzae dan Absidia corymbifera," Menara Perkeb., vol. 74, no. 1, pp. 23-32, 2006.

[19] R. Maceiras, M. Vega, C. Costa, P. Ramos, and M. C. Márquez, "Effect of methanol content on enzymatic production of biodiesel from waste frying oil," Fuel, vol. 88, no. 11, pp. 2130 2134, 2009.

[20] J. Sebastian, C. Muraleedharan, and A. Santhiagu, "A comparative study between chemical and enzymatic transesterification of high free fatty acid contained rubber seed oil for biodiesel production," Cogent Eng., vol. 3, pp. 1-12, 2016. 